\title{
Induction of cytotoxicity of Pelagia noctiluca venom causes reactive oxygen species generation, lipid peroxydation induction and DNA damage in human colon cancer cells
}

\author{
Yosra Ayed ${ }^{1}$, Manel Boussabbeh', Wiem Zakhama ${ }^{1}$, Chayma Bouaziz ${ }^{1}$, Salwa Abid ${ }^{1}$ and Hassen Bacha 1,2*
}

\begin{abstract}
Background: The long-lasting and abundant blooming of Pelagia noctiluca in Tunisian coastal waters compromises both touristic and fishing activities and causes substantial economic losses. Determining their molecular mode of action is, important in order to limit or prevent the subsequent damages. Thus, the aim of the present study was to investigate the propensity of Pelagia noctiluca venom to cause oxidative damage in HCT 116 cells and its associated genotoxic effects.

Results: Our results indicated an overproduction of ROS, an induction of catalase activity and an increase of MDA generation. We looked for DNA fragmentation by means of the comet assay. Results indicated that venom of Pelagia noctiluca induced DNA fragmentation. SDS-PAGE analysis of Pelagia noctiluca venom revealed at least 15 protein bands of molecular weights ranging from 4 to $120 \mathrm{kDa}$.

Conclusion: Oxidative damage may be an initiating event and contributes, in part, to the mechanism of toxicity of Pelagia noctiluca venom.
\end{abstract}

Keywords: Pelagia noctiluca, Jellyfish, Venom, Cytotoxicity, Oxidative stress, DNA fragmentation

\section{Background}

Pelagia noctiluca [1] (family Pelagiidae, Semaestomeae, Scyphozoa) is a highly venomous jellyfish species [2], widely distributed in different parts of the Mediterranean Sea [2,3] and in the Atlantic Ocean [5]. Pelagia noctiluca ( $P$. noctulica) has not caused human fatalities, but in spite of this, it can have profound ecological and socio-economic consequences when it appears in huge numbers during outbreaks [2-4].

As a matter of fact, events of massive occurrence of $P$. noctulica can be detrimental to aquaculture causing mortality of caged fish [6], to tourism by curtailing bathing activities [7], as for fishing activities, since in several cases, it was impossible to separate the biomass of medusae from fishes [8].

\footnotetext{
* Correspondence: hassen.bacha@fmdm.rnu.tn

'Laboratory for Research on Biologically Compatible Compounds, Faculty of Dentistry, Rue Avicenne, 5019 Monastir, Tunisia

Full list of author information is available at the end of the article
}

One of the most distinctive aspects of jellyfish physiology is related to its biologically active components and organelles contained in specialized cells called nematocysts. They are located along the tentacles and body. These organelles contain toxins and discharge their content upon an appropriate stimulation [9]. The venom of $P$. noctulica is of protein nature and contains peptides. It is antigenic and possesses dermonecrotic and hemolytic properties [10]; Cytolytic and neurotoxic effects have also been shown by several biological assays. The haemolytic effect is the most well studied activities of the venom [11-14]. Electrophoretical analyses recognized eight different fractions, distinguished by molecular mass [15].

The protein nature of venom [16] was further confirmed by Mariottini et al. [17]. P. noctiluca venom also caused an increase of ATP levels in treated cells followed by a moderate decrease [17]. This is an atypic response since most toxicity studies reported decrease

\section{C) Biomed Central}


of ATP levels in stress-exposed cells $[18,19]$ and organisms [20]. The toxicological nature of this venom has neither been characterized nor clearly described yet. Understanding the molecular mode of action of the cytosolic venom of $P$. noctulica is essential to predict their harmful effects on human health.

In this regard, our study aimed to evaluate the level of toxicity of P. noctiluca venom on HCT116 cells. We looked for the effects of the venom of $P$. noctiluca on cell viability, oxidative status and DNA fragmentation. To characterize the proteinous components of $P$. noctiluca venom, we separated the venom proteins using SDS-PAGE.

\section{Materials and methods}

\section{Chemicals}

3-4, 5-dimethylthiazol-2-yl, 2, 5-diphenyltetrazolium bromide (MTT), Cell culture medium (RPMI1640), foetal calf serum (FCS), phosphate buffer saline (PBS), trypsin-EDTA, penicillin and streptomycin mixture and lglutamine $(200 \mathrm{mM})$ were from GIBCO-BCL (UK). 2, 7Dichlorofluoresce diacetate (DCFH-DA) was supplied by Molecular Probes (Cergy Pontoise, France). Low melting point agarose (LMA) and normal melting point agarose (NMA) were purchased from Sigma (St. Louis, MO). All other chemicals used were of analytical grade.

\section{Preparation of nematocysts}

The nematocysts isolation method has been previously described by Arillo et al. [21]. Briefly, specimens of P. noctiluca were collected in the Strait of Monastir. The oral arms were excised and submerged in distilled water for 5 $\mathrm{h}$ at $4^{\circ} \mathrm{C}$. The ratio of organic tissue to distilled water was approximately 1:5. After a complete detachment of the epidermis the tissue was removed from the suspension containing both epidermis and undischarged nematocysts deriving from the osmotic rupture of nematocysts. The nematocysts, still attached to the epidermal tissue, were separated by stirring. The nematocysts suspension was repeatedly washed in distilled water and filtered through plankton nets (40, 60 and $100 \mu \mathrm{m}$ mesh, respectively) to remove most of the tissue debris, and then centrifuged at $4^{\circ} \mathrm{C}$ (ALC PK 120R, $4000 \mathrm{~g}$ for $5 \mathrm{~min}$ ). The content, purity and integrity of nematocysts (cnidocysts) were controlled microscopically, and the nematocysts concentrate was stored at $-80^{\circ} \mathrm{C}$ until further use [22].

\section{Nematocysts lysis and protein extraction}

Crude venom was extracted by sonication on ice (Sonoplus, $70 \mathrm{mHz}, 30$ times, $20 \mathrm{~s}$ ) of nematocysts as described by Marino et al. [22]. After sonication, the suspension was centrifuged at 11,000 rpm for $5 \mathrm{~min}$ at $4^{\circ} \mathrm{C}$. The supernatant was carefully removed, filtered and lyophilized.

\section{Protein determination}

The protein content was determined according to the Bradford method (BioRad Labs, Hercules, CA) [23]. In the following, all mention of "venom concentration" refers to protein concentration expressed in units of $\mu \mathrm{g}$ $\mathrm{ml}^{-1}$.

\section{Cell culture and treatment}

The human colon cancer cell line HCT 116 (wt) was gifted by Professor Olivier Micheau (Faculty of Medicine and Pharmacy, Univ. Bourgogne, Dijon). HCT 116 (wt) cells were grown as monolayer culture in RPMI 1640 medium (pH 7-8) supplemented with $10 \%$ fœtal calf serum (FCS), 1\% L-glutamine (200 mM), 1\% of mixture Penicillin $(100 \mathrm{IU} / \mathrm{ml})$ and Streptomycin $(100 \mu \mathrm{g} / \mathrm{ml})$ incubated at $37^{\circ} \mathrm{C}$ in an atmosphere of $5 \% \mathrm{CO} 2$.

\section{Determination of cell viability}

Cytotoxicity of pelagia crude venom was defined using the colorimetric method described by Carmichael et al. [24]. The MTT test assesses cell metabolism based on the ability of the mitochondrial succinate-dehydrogenase to convert the yellow compound MTT to a blue formazan dye. The amount of dye produced is proportional to the number of live metabolically active cells.

Cells were seeded on 96-well culture plates (Polylabo, France) at $10^{5}$ cells/well and treated with increasing concentrations of crude venom extract at $37^{\circ} \mathrm{C}$. After 24 $\mathrm{h}$, the culture medium was replaced by $200 \mu \mathrm{l}$ medium containing $0.5 \mathrm{mg} / \mathrm{ml} \mathrm{MTT}$ and the plates were incubated 3 hours at $37^{\circ} \mathrm{C}$. The medium was then removed and replaced by $200 \mu \mathrm{l}$ of $(0,04 \mathrm{M} \mathrm{HCl} /$ isopropanol $)$ to solubilize the converted purple dye in culture plates. The absorbance was measured on a spectrophotometer microplate reader (Dynatech 4000) at $545 \mathrm{~nm}$.

Cell viability was expressed as the relative formazan formation in treated samples as compared to control cells (untreated cells) [(A545 treated cells/A545 control cells) $100 \%$. The inhibitory concentration of $50 \%$ of cell viability (IC50) values defined as the concentration inducing $50 \%$ loss of cell viability.

\section{Measurement of reactive oxygen species (ROS) production by DCFH-DA method}

The intracellular amounts of ROS were measured by a fluorometric assay with 2', 7'-dichlorofluorescein diacetate (DCFH-DA) used extensively to monitor oxidation in biological systems as a well established compound to detect and quantify intracellular produced such as superoxide radical, hydroxyl radical, and hydrogen peroxide $[26,27]$. The conversion of the non-fluorescent (DCFH-DA) to the highly fluorescent 2', 7'- dichlorofluorescein product $(\mathrm{DCF})(\lambda \max =522 \mathrm{~nm})$ happens in many steps. The fluorescent probe, after diffusing in 
the cell membrane, is hydrolysed by intracellular esterases to non-fluorescent dichlorofluorescein (DCFH), which is trapped inside the cells then oxidized to fluorescent DCF through the action of peroxides in presence of ROS [28].

At $50 \%$ confluence, HCT 116 cells were incubated with different concentration of $\mathrm{P}$. noctiluca venom (80, 160,320 , and $640 \mu \mathrm{g} / \mathrm{ml}$ ) at a treatment time of $24 \mathrm{~h}$, a positive control was treated with $75 \mu \mathrm{M}$ of $\mathrm{H} 2 \mathrm{O} 2$ during $5 \mathrm{~min}$. Negative control corresponds to untreated cells. They were then treated with $20 \mu \mathrm{M}$ DCFH-DA. Intracellular production of ROS was measured after $30 \mathrm{~min}$ incubation at $37^{\circ} \mathrm{C}$ by fluorometric detection of DCF oxidation on a fluorimeter (Biotek FL $\times 800)$ with an excitation wavelength of $485 \mathrm{~nm}$ and emission wavelength of $522 \mathrm{~nm}$. The DCF fluorescence intensity is proportional to the amount of ROS formed intracellularly. Results are expressed as the ratio DCF- induced $P$. noctiluca venom fluorescence/DCF-induced control fluorescence.

\section{Determination of Catalase activity}

Catalase activity was measured in HCT116 cells extracts spectrophotometrically at $240 \mathrm{~nm}, 25^{\circ} \mathrm{C}$ according to Clairbone [29]. HCT 116 cells were seeded on 6-well culture plates (Polylabo, France) at $75 \times 10^{4}$ cells/well for $24 \mathrm{~h}$ of incubation. After, the cells were incubated with $P$. noctiluca crude venom at $80,160,320$, and 640 $\mu \mathrm{g} / \mathrm{ml}$, for $24 \mathrm{~h}$ at $37^{\circ} \mathrm{C}$. Briefly, $20 \mu \mathrm{l}$ of the cell extracts were added in the quartz cuvette contain $780 \mu \mathrm{l}$ phosphate buffer and $200 \mu \mathrm{l}$ of $\mathrm{H} 2 \mathrm{O} 20.5 \mathrm{M}$. The activity of catalase was calculated using the molar extinction coefficient $(0.04 \mathrm{mM}-1 \mathrm{~cm}-1)$. The results were expressed as $\mu \mathrm{mol}$ of $\mathrm{H} 2 \mathrm{O} 2 / \mathrm{min} / \mathrm{mg}$ of proteins.

\section{Lipid peroxidation}

Lipid peroxidation was assayed by the measurement of malondialdehyde (MDA) according to the method of Ohkawa et al. [30]. The cells were seeded in 6-well plates at $6 \times 10^{5}$ cells/well. After $24 \mathrm{~h}$ of incubation, they were exposed to different concentrations of $P$. noctiluca venom extract $(80,160,320$, and $640 \mu \mathrm{g} / \mathrm{ml})$ corresponding to IC50/4, IC50/2, IC50, and $2 \times$ IC50 s of crude venom in HCT 116 cells for $24 \mathrm{~h}$, followed by 1 $\mathrm{mM} \mathrm{H} 2 \mathrm{O} 2$ for $2 \mathrm{~h}$. The cells were then washed with cold PBS, scraped and lysed by homogenization in icecold $1.15 \% \mathrm{KCl}$. Samples containing $100 \mathrm{ml}$ of cell lysates were combined with $0.2 \mathrm{ml}$ of $8.1 \%$ SDS, $1.5 \mathrm{ml}$ of $20 \%$ acetic acid adjusted to $\mathrm{pH} 3.5$ and $1.5 \mathrm{ml}$ of $0.8 \%$ thiobarbituric acid. The mixture was brought to a final volume of $4 \mathrm{ml}$ with distilled water and heated to $95^{\circ} \mathrm{C}$ for $120 \mathrm{~min}$. After cooling to room temperature, 5 $\mathrm{ml}$ of mixture of $\mathrm{n}$ - butanol and pyridine (15:1, v:v) was added to each sample and the mixture was shaken vigorously. After centrifugation at 15, $000 \mathrm{rpm}$ for 10 min, the supernatant fraction was isolated and the absorbance measured at $532 \mathrm{~nm}$. The concentration of MDA was determined according to a standard curve.

\section{DNA damage assessed by the comet assay}

Comet assay, also known as single cell gel electrophoresis (SCGE), is a visual and sensitive technique for measuring DNA breakage in individual mammalian cells. HCT 116 cells were seeded on 6-well culture plates Polylabo, France) at $75 \times 10^{4}$ cells/well for $24 \mathrm{~h}$ of incubation and were re-incubated as described above in the presence of $P$. noctiluca crude venom at $80,160,320$, and $640 \mu \mathrm{g} / \mathrm{ml}$ for $24 \mathrm{~h}$ at $37^{\circ} \mathrm{C}$. H2O $2(75 \mu \mathrm{M})$ was used as a positive control. Approximately $2 \times 10^{4}$ cells were mixed with $1 \%$ low melting point agarose (LMP) in PBS and spread on a microscope slide previously covered with a $1 \%$ normal melting agarose (NMP) in PBS layer. After agarose solidification, cells were treated with an alkaline lysis buffer $(2.5 \mathrm{M} \mathrm{NaCl}, 0.1 \mathrm{M}$ EDTA, 10 $\mathrm{mM}$ Tris, $\mathrm{pH} 10,1 \%(\mathrm{v} / \mathrm{v})$ Triton $\mathrm{X}-100$ and $10 \%(\mathrm{v} / \mathrm{v})$ DMSO)for $1 \mathrm{~h}$ at $4^{\circ} \mathrm{C}$, then the DNA was allowed to unwind for $40 \mathrm{~min}$ in the electrophoresis buffer $(0.3 \mathrm{M}$ $\mathrm{NaOH}, 1$ mM EDTA, pH > 13). The slides were then subjected to electrophoresis in the same buffer for 30 $\min$ at $25 \mathrm{~V}$ and $300 \mathrm{~mA}$. Slides were then neutralized using a Tris buffer solution (0.4 M Tris, $\mathrm{pH} 7.5)$ for 15 $\mathrm{min}$. After staining the slides with ethidium bromide (20 $\mu \mathrm{g} / \mathrm{ml})$, the comets were detected and scored using a fluorescence microscope. The experiment was done in triplicate. The damage is represented by an increase of DNA fragments that have migrated out of the cell nucleus during electrophoresis and formed an image of a "comet" tail. A total of 100 comets on each slide were visually scored according to the intensity of fluorescence in the tail and classified by one of five classes as described by Collins et al., [31]. The total score was evaluated according to the following equation: (\% of cells in class $0 \times 0)+(\%$ of cells in class $1 \times 1)+(\%$ of cells in class $2 \times 2)+(\%$ of cells in class $3 \times 3)+(\%$ of cells in class $4 \times 4$ ).

\section{SDS-PAGE}

Protein species were observed by polyacrylamide gel electrophoresis (SDS-PAGE) as described previously [32]. Jellyfish venom protein $(200 \mu \mathrm{g})$ were diluted $(1: 1)$ with sample buffer (50 mM Tris pH 6.8, 2\% SDS, 20\% glycerol, 2\% 2- mercaptoethanol and 0.04\% bromophenol blue) and were then boiled for 3 min. Running gels of $5 \%$ acrylamide and stacking gels of $12 \%$ acrylamide were used. The gels were stained with Coomassie R-250. The molecular size marker, 6-170 kDa (protein standards, Invitrogen, CA, USA), was run parallel with venom sample for molecular weight estimation 


\section{Statistical analysis}

Each experiment was done three times separately. Values were presented as means \pm S.D. Statistical differences between control and treated groups for all expressions were determined by Student's test. Differences were considered significant at $\mathrm{P}<0.05$.

\section{Results}

\section{Inhibition of cell proliferation}

Cytotoxic effects of $P$. noctiluca crude venom on HCT 116 cells after $24 \mathrm{~h}$ incubation was measured by MTT assay. Results showed a dose-dependent inhibition of cell viability at increasing concentrations of $P$. noctiluca venom (Figure 1). The IC50 value as determined after $24 \mathrm{~h}$ of cell treatment from the viability curve was approximately about $320 \mu \mathrm{g} / \mathrm{ml}$.

\section{Oxidative status}

\section{1. Measurement of reactive oxygen species (ROS)} production

To check the oxidative stress status in HCT 116 cells in response of crude venom of $P$. noctiluca at different concentrations $(80,160,320$, and $640 \mu \mathrm{g} / \mathrm{ml})$ corresponding to IC50/4, IC50/2, IC50, and $2 \times$ IC50 s of crude venom), we measured the production of fluorescent DCF (the result of DCFH oxidation by a variety of peroxides). Results shown in Figure 2, demonstrated that crude venom induced an increase of ROS generation in a concentration manner (Figure 2). In fact, ROS production exceed $1.5 ; 1.7 ; 3$ and 4 fold to control for respectively IC50/4, IC50/2, IC50, and $2 \times$ IC50 s of crude venom in HCT 116 cells after 24 h. Positive control treated with $\mathrm{H} 2 \mathrm{O} 2(75 \mu \mathrm{M})$ which went beyond 7 fold to control (Figure 2).

\section{2. Catalase activity}

In order to investigate the responses of the reactive oxygen scavenging system of HCT 116 cells after $24 \mathrm{~h}$ of exposure to $P$. noctiluca venom the activity of catalase were measured. Results are illustrated in Figure 3. The catalase activity was found to be significantly increased in HCT 116 cells. It passed from $0.15 \pm 0.08$ in control cells (untreated cells) to $0.61 \pm 0.095 \mu \mathrm{mol}$ of $\mathrm{H} 2 \mathrm{O} 2$ decomposed $/ \mathrm{min} / \mathrm{mg}$ of protein in treated cells with the highest concentration of Pelagia crude venom $(640 \mu \mathrm{g} /$ $\mathrm{ml})$.

\section{3. Induction of lipid peroxidation}

$P$. noctiluca venom induced lipid peroxidation. Indeed, after $24 \mathrm{~h}$ incubation with different concentration of crude venom $(80,160,320$, and $640 \mu \mathrm{g} / \mathrm{ml})$, the MDA level detected in HCT 116 cells increased from basal value of $0.78 \pm 0.1 \mu \mathrm{M}$ at $80 \mu \mathrm{g} / \mathrm{ml}$ of pelagia venom (p $<0.05)$ to $2.6 \pm 0.18 \mu \mathrm{M}(\mathrm{p}<0.05)$ at $640 \mu \mathrm{g} / \mathrm{ml}$ of crude venom (Figure 4).

\section{Effect of the venom on DNA damage assessed by the comet assay}

DNA damage was analyzed using the Comet assay; a sensitive method for detecting DNA strand breaks in individual cells, and a versatile tool that is highly efficacious in human bio-monitoring of natural or

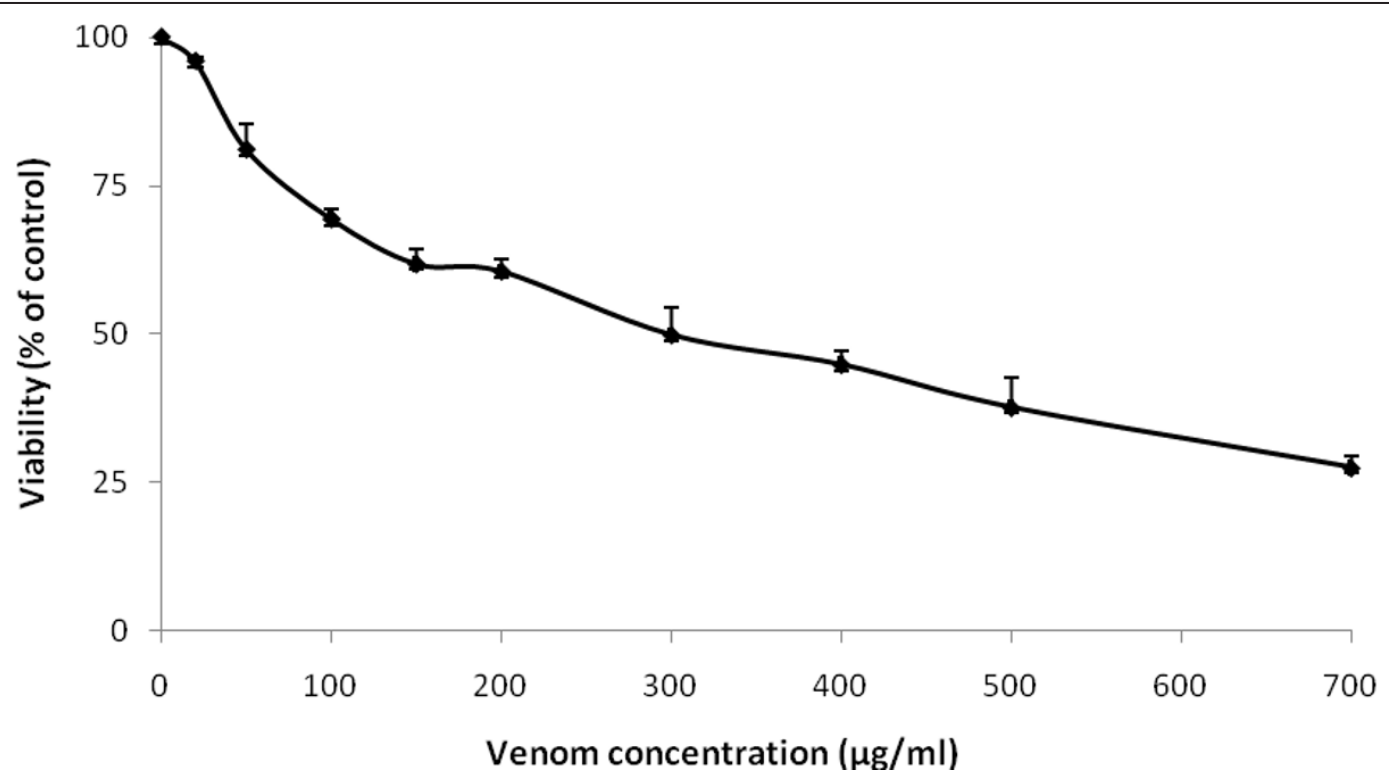

Figure 1 Cytotoxic effect of $P$. noctiluca crude venom on HCT 116 cells. Cells were treated with venom at the indicated concentrations for $24 \mathrm{~h}$. Cell viability was determined using the MTT assay and expressed as percentages of control which was exposed to vehicle only. Control value was taken as 100\%. Data are expressed as the mean \pm S.D. 


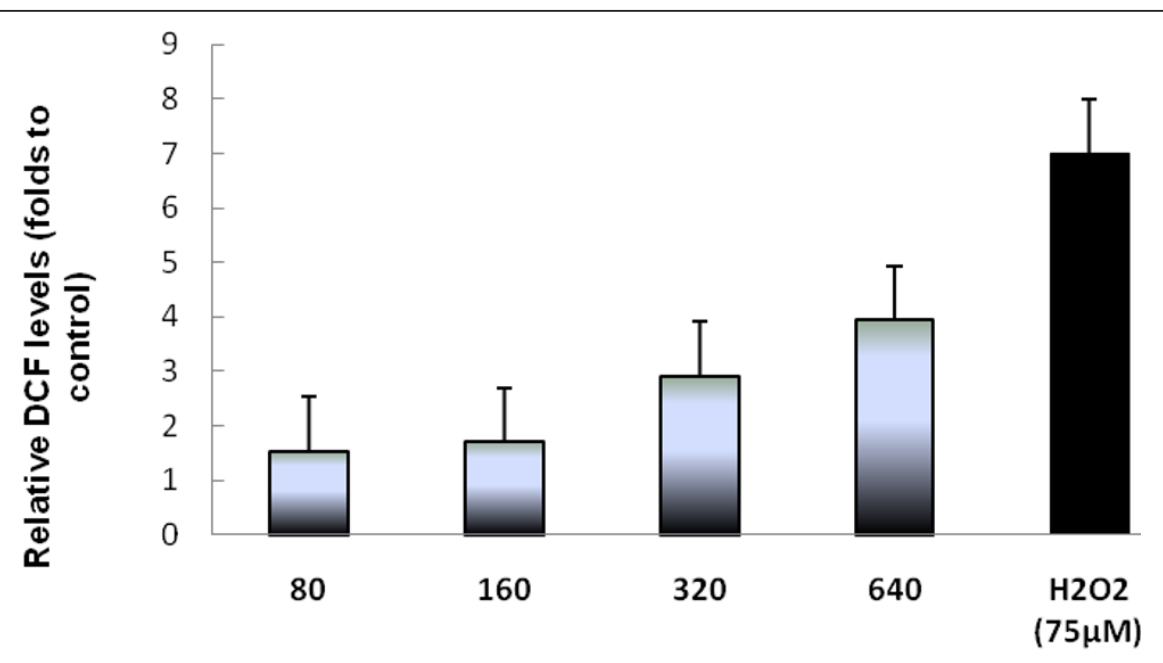

Venom concentrations $(\boldsymbol{\mu g} / \mathrm{ml})$

Figure 2 Levels of relative fluorescent DCF production, after exposure of HCT 116 cells to 80, 160, 320, and $640 \mu \mathrm{g} / \mathrm{ml}$ corresponding to IC50/4, IC50/2, IC50, and $2 \times$ IC50 s of crude venom of $P$. noctiluca for $\mathbf{2 4} \mathbf{h}$. Fluorescent DCF is the result of DCFH oxidation by a variety of peroxides. $\mathrm{H} 2 \mathrm{O} 2,75 \mu \mathrm{M}$ was used as a positive control. This graph is a representative of three independent experiments. Data are expressed as the mean \pm S.D.

environmental compounds [33]. The high sensitivity of the Comet assay, and the provided ability to measure DNA damage in individual cells, has destined it to become a tool in rapidly predicting genotoxicity of compounds of interest. The induction of DNA damage in HCT 116 cells after exposure to crude venom of $P$. noctiluca for $24 \mathrm{~h}$ was studied. The amount of DNA damage reaches about 3 folds to the control value after $24 \mathrm{~h}$ of crude venom at the highest concentration. Indeed, as shown in Figure 5, crude venom extract at concentrations of IC50/4, IC50/2, IC50, and $2 \times$ IC50, induced $87.6 \pm$ $2.08,107.6 \pm 3.51,137.6 \pm 4.04$ and $198.66 \pm 9.5$ of total score of DNA damage as compared to $59.6 \pm 2.08$ of the score in control cells (untreated cells). $\mathrm{H}_{2} \mathrm{O}_{2}(75 \mu \mathrm{M})$ treated cells (positive control) formed a clear comet of more than 7 folds of untreated control cells (Figure 5).

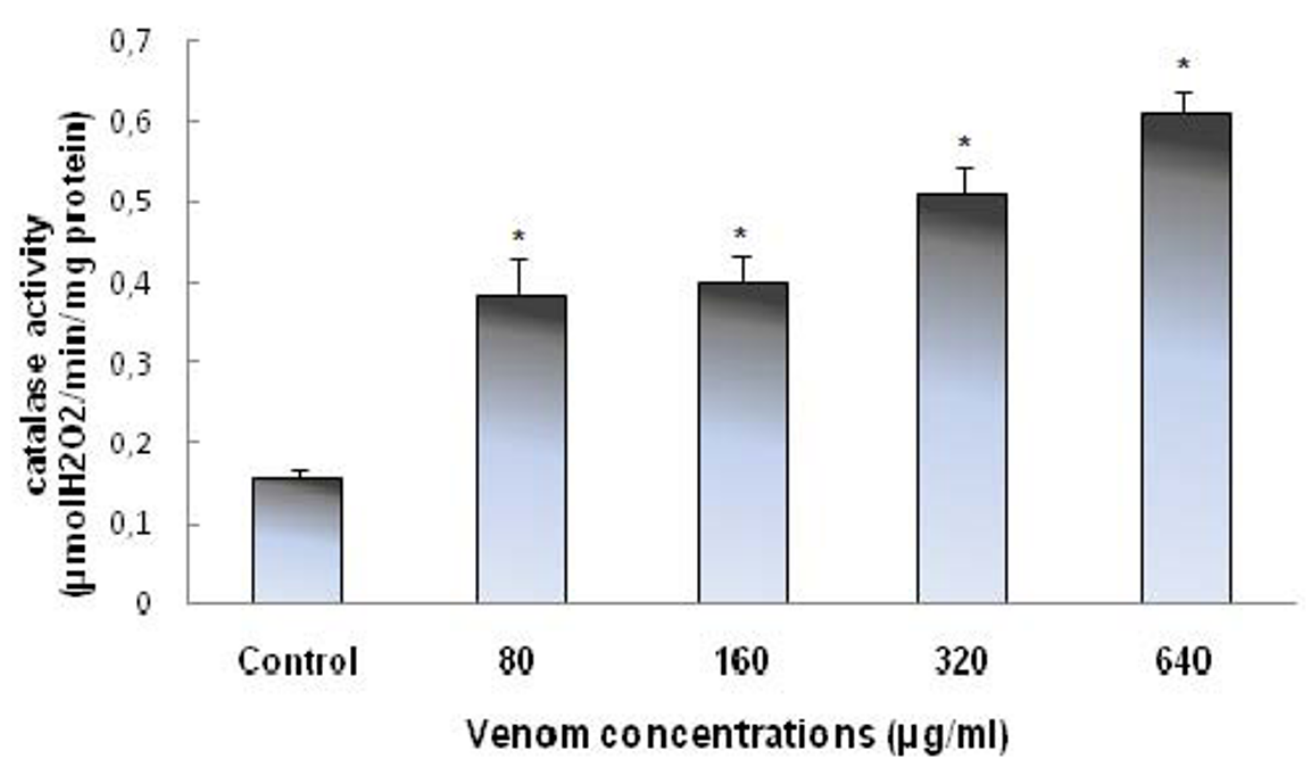

Figure $3 P$. noctiluca crude venom induced catalase activity on HCT 116 cells after $24 \mathbf{h}$ of treatment. Results are expressed as mean \pm S. D from three independent experiments. *Values are significantly different at $p<0.05$ as compared to the control. 


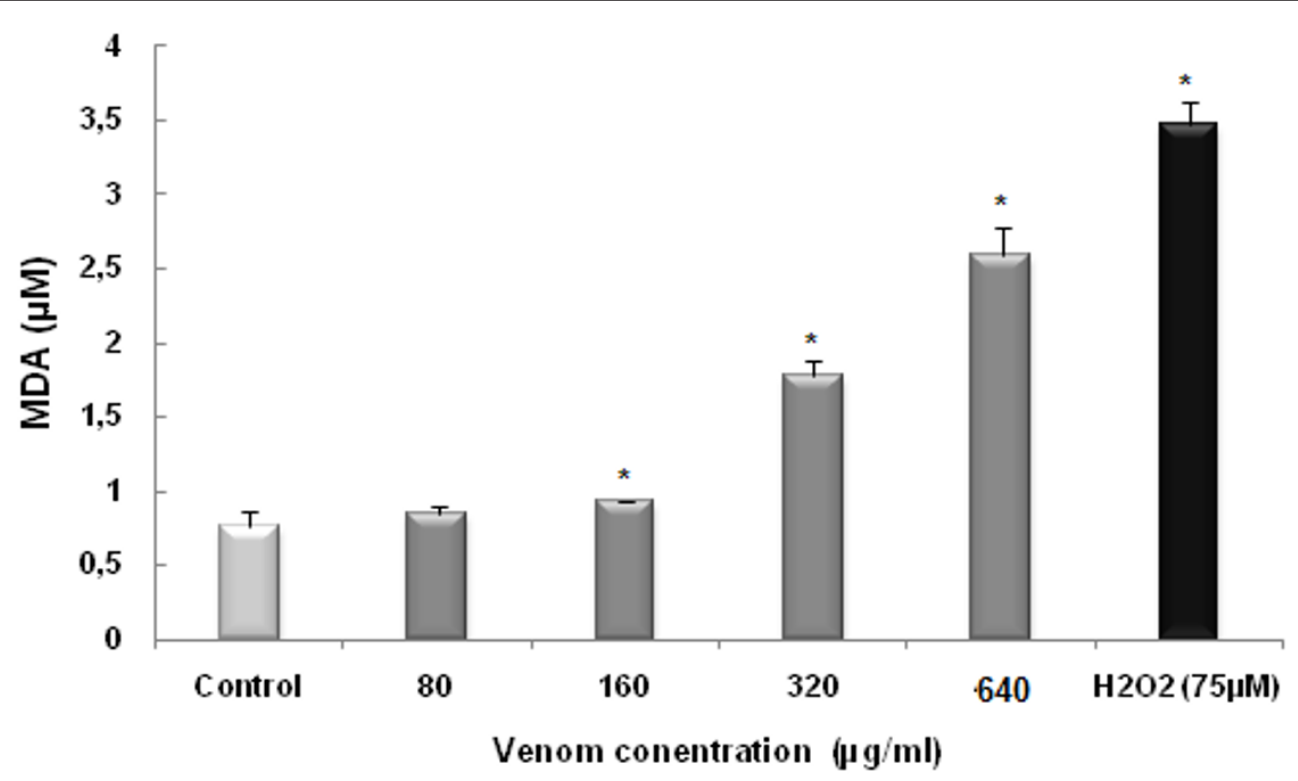

Figure 4 Lipid peroxidation induced in HCT 116 cells, incubated for $24 \mathrm{~h}$ with venom of $P$. noctiluca at $80,160,320$, and $640 \mu \mathrm{g} / \mathrm{ml}$, measured by the production of malondialdehyde (MDA). Results were expressed as means \pm S.D. from at least three independent experiments. * Values are significantly different at $p<0.05$ as compared to the control.

\section{SDS-PAGE of $P$. noctiluca Venom}

Electrophoretical analysis of $P$. noctiluca Venom revealed a number of bands of varying size (Figure 6). 15 bands appeared after staining of the SDS-PAGE gel. The molecular mass of these bands was $120 ; 115 ; 80$; 70 ; 66; 64; $55 ; 45 ; 37 ; 33 ; 29 ; 20 ; 16 ; 14 ; 4 \mathrm{kDa}$, respectively. The components of jellyfish venom were complex.

\section{Discussion}

Oxidative stress is a term commonly used to denote the imbalance between the concentrations of reactive oxygen species (ROS) and the antioxidative defense mechanisms of the body. Compelling evidences suggest that an excess of ROS production to such an extent that cellular defences are overwhelmed and the cell is

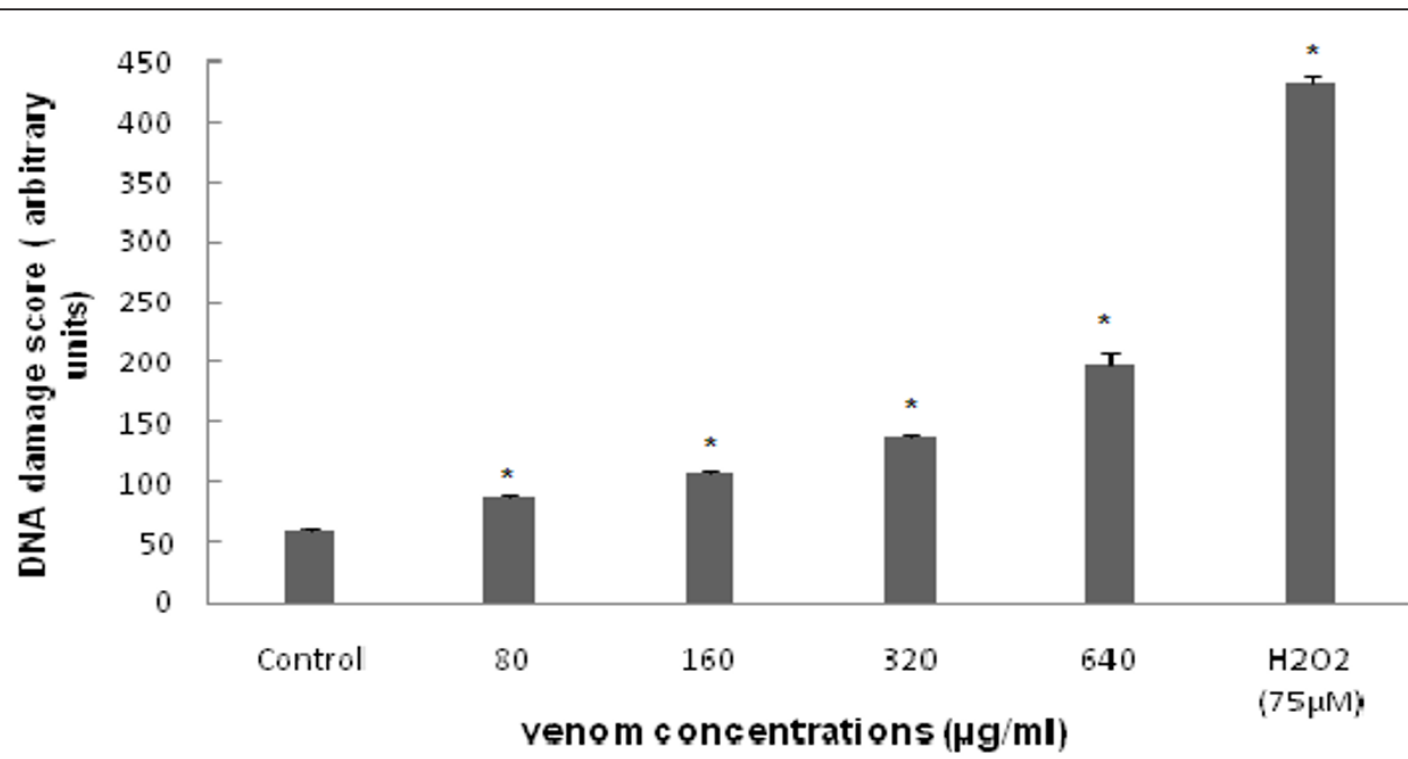

Figure 5 Total DNA damage observed on HCT116 cells after treatment with Pelagia venom $(80,160,320$, and $640 \mu \mathrm{g} / \mathrm{ml}) \mathrm{for} 24 \mathrm{~h}$ of treatment. $\mathrm{H} 2 \mathrm{O} 2(75 \mu \mathrm{M})$ was used as a positive control. DNA stand breaks were detected by the standard comet assay. ${ }^{*}$ Values are significantly different at $\mathrm{p}<0.05$ as compared to the control. 


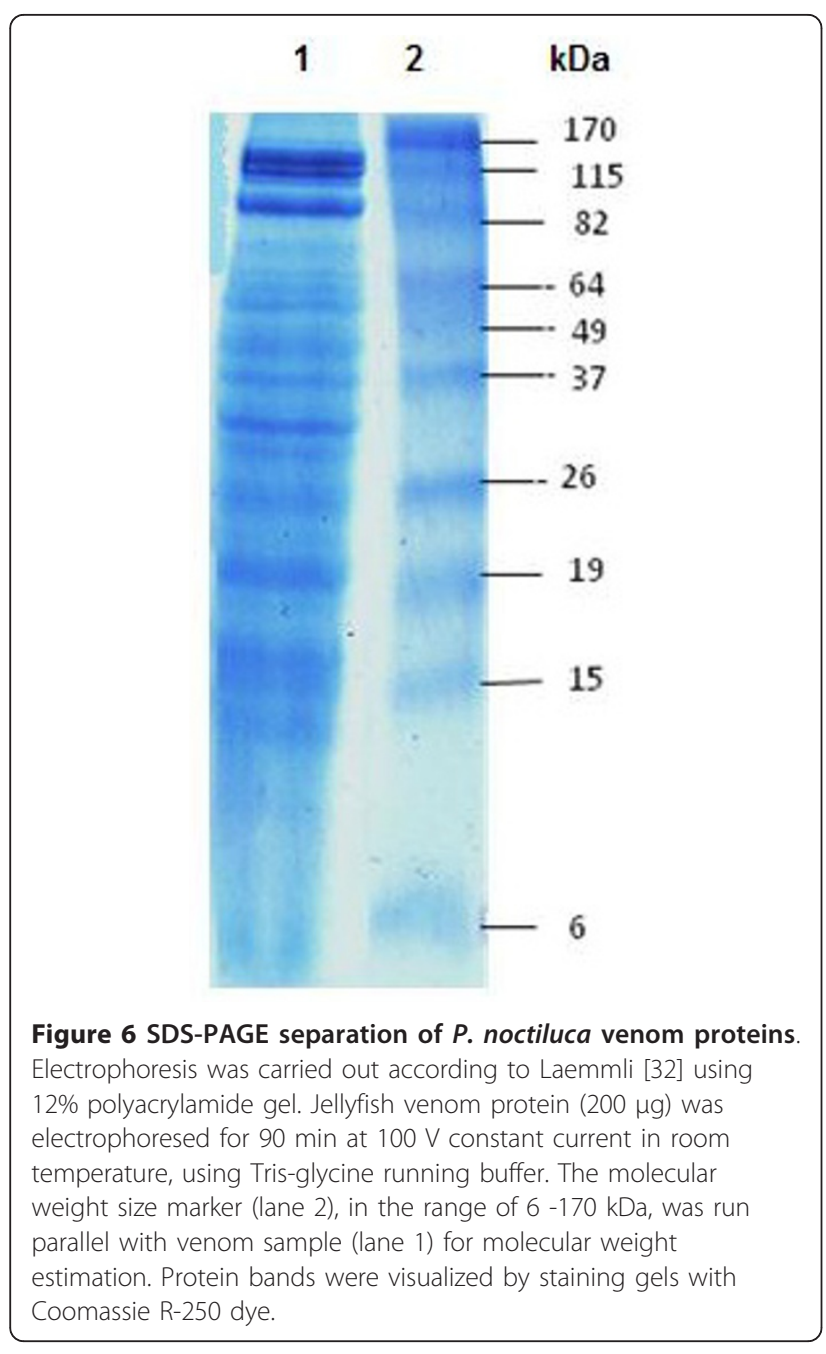

injured, is largely considered as playing a key role in a variety of human diseases $[34,35]$. To counteract the detrimental effects of oxidative stress, cells deploy antioxidant defenses, activate damage removal and repair systems, and mount adaptive responses [36]. To assess oxidative stress, several methods are available and are based either on the measurement of the stable peroxidation products (mainly lipid peroxidation products, oxidized proteins and DNA oxidation biomarkers) or the measurements of antioxidants agents.

In our laboratory, a special attention was given to the study of jellyfish toxicity signaling pathways. P. noctiluca is the most venomous Mediterranean Scyphozoa [4-6] which represents a danger to sea bathers and causes fishery damages in the Mediterranean Sea. In fact, excluding haemolytic and cytotoxic effects, the celldamaging action of cnidarians toxins is greatly unknown [7-42].

Hence, our purpose was to investigate the propensity of $P$. noctiluca venom to cause oxidative damage in
HCT 116 cells and its associated genotoxic effect. Oxidative stress was monitored by measuring reactive oxygen species (ROS) and malondialdehyde levels, and by evaluating catalase activity. We further looked for DNA fragmentation by means of the Comet assay.

The effect of venom of $P$. noctiluca on the inhibition of cell proliferation was assessed by MTT assay in HCT 116 cells (Figure 1). A dose-dependent decrease in cell viability was clearly observed with increasing concentrations of $P$. noctiluca venom and we determined the IC50 after $24 \mathrm{~h}$ which is about $320 \mu \mathrm{g} / \mathrm{ml}$ by MTT assay. Our findings are in accordance with previous data from Mariottini et al. [17] who demonstrated the cytotoxic properties of $P$. noctiluca nematocysts venom that have been experimentally assessed on cultured cells.

There are previous literatures, including the IC50 values of jellyfish venoms from Chrysaora quinquecirrha on CCL-13 hepatocyte (IC50 $<1 \mu \mathrm{g} / \mathrm{mL}$ ) [43], from Cyanea capillata on HepG2 hepatoma cells for $48 \mathrm{~h}$ (IC50 $=20.3 \mu \mathrm{g} / \mathrm{mL})$ [14], and from nematocyst free-tissue of Rhizostoma pulmo on V79 lung fibroblast for $3 \mathrm{~h}$ $(\mathrm{IC} 50=37.6 \mu \mathrm{g} / \mathrm{mL})[44]$.

Mechanisms whereby the venom of $P$. noctiluca induced the cytotoxic effect are still not understood. Until now, there are no available data regarding the involvement of oxidative stress induced in vitro after pelagia venom exposure. To evaluate the ability of pelagia venom to generate an oxidative stress status, we choose to monitor one of the earliest responses of oxidative stress which is the increase in ROS levels in cells.

Techniques using fluorescent probes have made it possible to estimate ROS in biological samples, allowing their use as an indicator of oxidative stress. So, we have measured ROS production after Pelagia venom treatment using DCFH-DA as a fluorescent probe. We have found that increasing concentrations of $P$. noctiluca venom promoted an increase in the production of the fluorescent DCF and consequently a significant ROS generation in a concentration dependent manner (Figure 2).

Levels of early markers of oxidative stress including antioxidant enzymes, may be altered in the presence of lower levels of oxidative stress. To this end, we have monitored the catalase activity. Our results clearly showed that $P$. noctiluca venom enhances catalase activity (Figure 3 ). The induction of the enzymatic antioxidant defenses after the exposure to pelagia venom could be considered as an adaptive response; that is, a compensatory mechanism that enables cells to overcome the damage caused.

To further demonstrate the implication of oxidative stress in venom induced toxicity, we choose to monitor lipid peroxidation. Lipid peroxidation is one of the suggested cytotoxic mechanisms of jellyfish venom. The 
MDA is an end product of lipid peroxidation, considered as a late biomarker of oxidative stress and cellular damage [45]. It is generally considered as an excellent index of lipid peroxidation [46-48]. We have shown an increase of lipid peroxidation level which seemed related to pelagia crude venom concentrations as inferred by the amount of MDA generated, confirming an increase of free radicals production. This fact emphasizes that the oxidative damage is induced by the venom of $P$. noctiluca in cultured HCT 116 cells (Figure 4).

These results are in accordance with a recent study of Marino et al. [42] who demonstrated that venom of $P$. noctiluca induced inflammation which was characterized by lipid peroxidation in vivo [42].

Previous studies indicated that jellyfish venoms were able to induce oxidative stress in cells. Indeed, crude venom from the sea anemone Stichodactyla helianthus induces peroxidative damage in rat and human erythrocytes [49], besides, Santamaría et al., [50] described that both haemolysis and Lipid peroxidation enriched significant levels in mice erythrocytes as a response to similar concentrations of venom extracts of the Caribbean sea anemone Bartholomea annulata. In addition, the haemolytic response resulted sensitive when exposed to antioxidant agents, and we hypothesized that Lipid peroxidation might have been a causative factor of haemolysis. However, our results differ from Marino et al. [22] who pointed out controversially that the hemolysis caused by $P$. noctiluca venom may not be due to free radical formation [22].

It is well known that ROS can induce a number of molecular alterations on cellular components, leading to changes in cell morphology and viability [51]. Overproduction of ROS may induce cell oxidative injury, such as DNA damage [52] leading to genotoxic process [53]. In addition, MDA is a potentially important contributor to DNA damage and mutation [54]. Therefore, we checked if pelagia venom was able to induce genotoxicity in HCT 116 cells. For this, we monitored the comet assay (Single-cell gel electrophoresis) which has become a sensitive and rapid method for the detection of DNA damage by strand breaks, open repair sites, crosslinks, and labile sites at the individual cell level. This assay was considered as a predictor of genotoxic activity of chemicals in animal and human cells [55]. Significant increase in DNA damage score showed a concentrationrelated elevation after treatment with venom of $P$. noctiluca. This induction of DNA damage was associated with pelagia venom-induced oxidative stress. In fact, ROS induction and lipid peroxidation seems to be responsible for venom-induced DNA strand breakage.

Protein components of $P$. noctiluca jellyfish venom were separated by using SDS-PAGE, electrophoretical analysis revealed at least 15 protein bands ranging in molecular weights from 120 to $4 \mathrm{kDa}$ (Figure 6). This suggests the complexity of this venom. We have now no evidence, however, whether some of these proteins contribute to the toxic activities of this jellyfish venom, which was observed in the present study.

In conclusion, our study implicates cytotoxicity, oxidative pathways and DNA lesions demonstrated by DNA fragmentation in the venom of $P$. noctiluca toxicities. These toxic activities might be attributed to the protein nature of the venom. Further biochemical investigations are in progress to characterize the different proteinic components of $P$. noctiluca venom from a toxicological study and to clarify their mechanism of action.

\section{List of Abbreivations}

Pelagia noctiluca: P. noctulica; ATP: Adenosine-5'-triphosphate; ROS: Reactive oxygen species; DCFH-DA: 2', 7'-dichlorofluorescein diacetate; DCF: 2', 7'- dichlorofluorescein; MDA: Malondialdehyde level; LMP: Low melting point agarose; NMP: Normal melting agarose; IC50: the concentration inducing $50 \%$ loss of cell viability.

\section{Acknowledgements}

This research was supported by the "Ministère Tunisien de l'Enseignement Supérieur, de la Recherche Scientifique et de la Technologie" through the "Laboratoire de Recherche sur les Substances Biologiquement Compatibles".

\section{Author details}

'Laboratory for Research on Biologically Compatible Compounds, Faculty of Dentistry, Rue Avicenne, 5019 Monastir, Tunisia. ${ }^{2}$ University of Jendouba, Cité AlFaeiz rue Jamil Boutheina Jendouba 8100, Tunisia.

\section{Authors' contributions}

YA carried out the studies, acquired the data, performed the data analysis, and drafted the manuscript. MB played a major role in the experimental procedures of this study. WZ carried out the statistical analysis. CB revised the manuscript. $\mathrm{SA}$ and $\mathrm{HB}$ involved in the design and organization of the study and interpreted the results. All authors have read and approved the final manuscript.

\section{Competing interests}

The authors declare that they have no competing interests.

Received: 26 October 2011 Accepted: 9 December 2011

Published: 9 December 2011

\section{References}

1. Forskal: Medusae: Descriptiones Animalium, avium, amphibiorum, piscium, insectorum, vermium Postmortem auctoris edidit Carsten Niebuhr. Hauniae 1775, 1:106-111.

2. Licandro P, Conway DVP, Daly Yahia MN, Fernandez de Puelles ML, Gasparini S, Hecq JH, Tranter P, Kirby RR: A blooming jellyfish in the northeast Atlantic and Mediterranean. Biol Lett 2010, 6:688-691.

3. Malej A, Malej A Jr: Invasion of the jellyfish Pelagia noctiluca in the northern Adriatic: a non-success story. In Aquatic Invasions in the Black, Caspian and Mediterranean Seas. Volume 16. Edited by: Dumont H, Shiganova T, Niermann U. Kluwer Academic Publishers: Dordrecht, The Netherlands; 2004:273-285, Eds.

4. Mariottini GL, Giacco E, Pane L: The mauve stinger Pelagia noctiluca (Forsskål, 1775). Distribution, ecology, toxicity and epidemiology of stings. A review. Mar Drugs 2008, 6(3):496-513. 
5. Doyle TK, De Haas H, Cotton D, Dorschel B, Cummins V, Houghton JDR Davenport J, Hays GC: Widespread occurrence of the jellyfish Pelagia noctiluca in Irish coastal and shelf waters. J Plankton Res 2008, 30:963-968.

6. Delannoy CMJ, Houghton JDR, Fleming NEC, Ferguson HW: Mauve Stingers (Pelagia noctiluca) as carriers of the bacterial fish pathogen Tenacibaculum maritimum. Aquaculture 2011, 311:255-257.

7. Purcell JE, Uye SI, Lo T: Anthropogenic causes of jellyfish blooms and their direct consequences for humans. A review Mar Ecol Prog Ser 2007, 350:153-174.

8. Mariottini GL, Pane L: Mediterranean jellyfish venoms: a review on Scyphomedusae. Mar Drugs 2010, 8:1122-52

9. Kang C, Munawir A, Cha I, Sohn MT, Lee H, Kim JS, Yoon WD, Lim D, Kim E: Cytotoxicity and hemolytic activity of jellyfish Nemopilema nomurai (Scyphozoa: Rhizostomeae) venom. Comparative Biochemistry and Physiology Part C 2009, 150:85-90

10. Maretic Z: The bloom of jellyfish Pelagia noctiluca along the coasts of Pula and Istria 1977-1983 with special reference to epidemiology, clinics and treatment. UNEP: Workshop on Jellyfish Blooms in the Mediterranean 1984, 83-87.

11. Eno $A E$, Konya RS, Ibu JO: Biological properties of a venom extract from the sea anemone Bunodosoma cavernata. Toxicon 1998, 36:2013-2020.

12. Bruhn T, Schaller C, Schulz C, Sanchez-Rodriguez J, Dannmeier C, Ravens U, Heubach JF, Eckhardt K, Schmidtmayer J, Schmidt H, Aneiros A, Wachter E, Béress $\mathrm{L}$ : Isolation and characterization of five neurotoxic and cardiotoxic polypeptides from the sea anemone Anthopleura elegantissima. Toxicon 2001, 39(5):693-702.

13. Hinds MG, Anderluh G, Hansen PE, Norton RS: Solution structureof the eukaryotic pore-forming cytolysin equinetoxin II: implications for pore formation. J Mol Biol 2002, 315:1219-1229.

14. Helmholz H, Ruhnau C, Schütt C, Prange A: Comparative study on the cell toxicity and enzymatic activity of two northern scyphozoan species Cyanea capillata (L.) and Cyanea lamarckii (Péron \& Léslieur). Toxicon 2007, 50:53-64

15. Maretic Z, Matic-Piantanida D, Ladavac J: The bloom of the jellyfish Pelagia noctiluca in the Mediterranean and Adriatic and its impact on human health. UNEP: Jellyfish blooms in the Mediterranean, Proceedings of the II Workshop on Jellyfish in the Mediterranean Sea. MAP Technical Reports Series 1991, 47:260-267.

16. Togias AG, Burnett JW, Kagey-Sobotka A, Lichtenstein LM: Anaphylaxis after contact with a jellyfish. J Allergy Clin Immunol 1985, 75:672-675

17. Mariottini GL, Sottofattori E, Mazzei M, Robbiano L, Carli A: Cytotoxicity of the venom of Pelagia noctiluca Forskal (Cnidaria: Scyphozoa). Toxicon 2002, 40:695-698.

18. Önfelt A: Spindle disturbances in mammalian cells. IV. The action of some glutathione-specific agents in V79 Chinese hamster cells, changes in levels of free sulfhydryls and ATP, c-mitosis and effects on DNA metabolism. Mutat Res 1987, 182:155-172.

19. Miles PR, Bowman L, Ma JKH, Ma JYC: Alterations in alveolar type II cells metabolism induced by Tetrandrine and other alkaloids. Toxicol Appl Pharmacol 1993, 119:142-149.

20. Antonietti R: The measure of ATP flows in microbial communities: first results. Verh Int Verein Limnol 1985, 22:2768-2772.

21. Arillo A, Burlando B, Carli A, Mariottini GL: Mitochondrial alteration caused by cnidarians toxins: a preliminary study. Boll Soc It Biol Sper 1994 70:307-313.

22. Marino A, Morabito R, Pizzata T, La Spada G: Effect of various factors on Pelagia noctiluca (Cnidaria, Scyphozoa) crude venom-induced haemolysis. Comp Biochem Physiol A 2008, 151:144-149.

23. Bradford MM: A rapid and sensitive method for the quantification of microgram quantities of protein utilizing the principle of protein-dye binding. Anal Biochem 1976, 72:248-254

24. Carmichael J, De Graff WG, Gadza AF, Minna JD, Mitchell J: Evaluation of a tetrazolium-based semi-automated colorimetric assay: assessment of chemosensitivity testing. Cancer Res 1987, 47:936-942.

25. Cathcart R, Schwiers E, Ames BN: Detection of picomole levels of hydroperox- ides using a fluorescent dichlorofluorescein assay. Anal Biochem 1983, 134(1):111-6.

26. Gomes A, Fernandes E, Lima JL: Fluorescence probes used for detection of reactive oxygen species. J Biochem Biophys Methods 2005, 65:45-80.

27. Chen T, Wong YS: Selenocystine induces caspase-independent apoptosis in MCF-7 human breast carcinoma cells with involvement of $p 53$ phosphorylation and reactive oxygen species generation. Int J Biochem Cell Biol 2009, 41:666-76.

28. Le Bel CP, Ischiropoulos H, Bondy SC: Evaluation of the probe 2-, 7dichlorofluorescein as an indicator of reactive oxygen species formation and oxidative stress. Chem Res Toxicol 1992, 5:227-31.

29. Clairbone A: Catalase activity. Handbook of Methods for Oxygen Radical Research. CRC Press Boca Raton FL 1985, 283-284.

30. Ohkawa H, Ohishi $\mathrm{N}$, Yagi $\mathrm{K}$ : Assay for lipid peroxide in animal tissues by thiobarbituric acid reaction. Anal Biochem 1979, 95:351-358.

31. Collins AR, Dusinska M, Gedik CM, Stetina R: Oxidative damage to DNA: do we have a reliable biomarker? Environ Health Perspect 1996, 104:465-9.

32. Laemmli UK: Cleavage of structural proteins during the assembly of the head of bacteriphage T4. Nature 1970, 227:680-685.

33. Aruoma OI: Antioxidant action of plant foods: use of oxidative DNA damage as a tool for studying antioxidant efficacy. Free Radic Res 1999, 30:419-27.

34. Halliwell B, Gutteridge JMC: Free Radicals in Biology and Medicine Oxford University Press Oxford; 1999

35. Calabrese V, Renis M, Calderone A, Russo A, Reale S, Barcellona ML, Rizza V: Stress proteins and $\mathrm{SH}$ groups in oxidant-induced cell injury after chronic ethanol administration in rat. Free Radic Biol Med 1998, 24:1159-1167.

36. Thannickal J, Fanburg BL: Reactive oxygen species in cell signaling. American Journal of Physiology 2000, 27:1005-1028.

37. Batista U, Macek P, Sedmak B: The influence of equinatoxin II on V-79-379 A cell line. Period Biol 1986, 88:97-98.

38. Batista U, Macek P, Sedmak B: The cytotoxic and cytolytic activity of equinatoxin II from the sea anemone Actinia equina. Cell Biol Int Rep $1990,14: 1013-24$

39. Batista U, Jezernik K: Morphological changes of V-79 cells after equinatoxin II treatment. Cell Biol Int Rep 1992, 16:115-23.

40. Mariottini GL, Bussotti S, Carli A: Cytotoxic effects produced on a continuous cell line by the nematocyst venom of Anemonia sulcata (Cnidaria: Anthozoa). I. Cytotechnology 1993, 11:158-159.

41. Allavena A, Mariottini GL, Martelli A, Carli A: In vitro cytotoxic activity of the tissular toxin of Rhizostoma vulmo Aeassiz (Cnidaria: Scvnhozoa). Pharmac Toxic 1995, 76:31.

42. Marino A, Di Paola R, Crisafulli C, Mazzon E, Morabito R, Paterniti I, Galuppo M, Genovese T, La Spada G, Cuzzocrea S: Protective effect of melatonin against the inflammatory response elicited by crude venom from isolated nematocysts of Pelagia noctiluca (Cnidaria, Scyphozoa). J Pineal Res 2009, 47:56-69

43. Cao CJ, Eldefrawi ME, Eldefrawi AT, Burnett JW, Mioduszewski RJ, Menking $D E$, Valdes JJ: Toxicity of sea nettle toxin to human hepatocytes and the protective effects of phosphorylating and alkylating agents. Toxicon 1998, 36(2):269-281.

44. Allavena A, Mariottini GL, Carli AM, Contini S, Martelli A: In vitro evaluation of the cytotoxic, cytolytic and clastogenic activities of Rhizostoma pulmo toxin. Toxicon 1998, 36:933-936.

45. Vaca CE, Wilhelm J, Hartwig A, Harms-Ringgdahl M: Interaction of lipid peroxidation products with DNA. A review Mutat Res 1988, 195:137-149.

46. Bird RP, Draper HH: Effect of malondialdehyde on cultured mammalian cells; growth, morphology and synthesis of macromolecules. J Toxicol Environ Health 1980, 6:811-823.

47. Wendel A, Reiter R: In vitro Assesment of hepatic lipid peroxidation by malondialdehyde orethane determination. In Dans: oxygen radicals in chemistery and biology. Edited by: Bors W, Saran M, Tait D. Berlin, Walter de Gruyter and CO; 1984:345-349, eds.

48. Tomita M, Okuyama T: Determination of malondialdehyde in oxidized biological materials by high-performance liquid chromatography. $J$ Chromatogr 1990, 515:391-397.

49. Monroy-Estrada HI, Segura-Puertas L, Galván-Arzate S, Santamaría A, Sánchez-Rodríguez J: The crude venom from the sea anemone Stichodactyla helianthus induces haemolysis and slight peroxidative damage in rat and human erythrocytes. Toxicology in Vitro 2007, 21:398-402.

50. Santamaría A, Sánchez-Rodríguez J, Zugasti A, Martínez A, Galvan- Arzate S, Segura-Puertas L: A venom extract from the sea anemone Bartholomea annulata produces haemolysis and lipid peroxidation in mouse erythrocytes. Toxicology 2002, 173:221-228. 
51. Sies H: Oxidative stress: introductory remarks. In Oxidative stress. Edited by: Sies H. London: Academic Press; 1985:, editor.

52. Matés JM: Effects of antioxidant enzymes in the molecular control of reactive oxygen species toxicology. Toxicology 2000, 16:83-104.

53. Epe B: Genotoxicity of singlet oxygen. Review Chem Biol Interact 1991, 80(3):239-60.

54. Esterbauer $\mathrm{H}$ : Cytotoxicity and genotoxicity of lipid-oxidation products. Am J Clin Nutr 1993, 57:779-786.

55. Collins AR, Oscoz AA, Brunborg G, Gaivão I, Giovannelli L, Kruszewski M, Smith CC, Stetina R: The comet assay: topical issues. Mutagenesis 2008, 23(3):143-51.

doi:10.1186/1476-511X-10-232

Cite this article as: Ayed et al: Induction of cytotoxicity of Pelagia noctiluca venom causes reactive oxygen species generation, lipid peroxydation induction and DNA damage in human colon cancer cells. Lipids in Health and Disease 2011 10:232.

Submit your next manuscript to BioMed Central and take full advantage of:

- Convenient online submission

- Thorough peer review

- No space constraints or color figure charges

- Immediate publication on acceptance

- Inclusion in PubMed, CAS, Scopus and Google Scholar

- Research which is freely available for redistribution

Submit your manuscript at www.biomedcentral.com/submit
C BioMed Central 